\title{
SECURED BAD DEBTS: MANIPULATION OF DEDUCTIONS BY POSTPONING LIQUIDATION OF SECURITY*
}

The Internal Revenue Code allows a deduction for a loss resulting when a debt owing to a taxpayer becomes worthless within the taxable year. ${ }^{1}$ Business bad debts are fully deductible from ordinary income, ${ }^{2}$ and deductions are permitted for partial worthlessness. ${ }^{3}$ On the other hand, nonbusiness bad debts are deductible only as short term capital losses, ${ }^{4}$ and deductions for partial worthlessness are not allowed. ${ }^{5}$ The tax effect of security on a debt that would

*Loewi v. Ryan, 229 F.2d 627 (2d Cir. 1956).

1. "There shall be allowed as a deduction any debt which becomes worthless within the taxable year." INT. REv. CODE of 1954, § 166(a) (1).

There can be no bad debt deduction without a valid debt. Harmount v. Commissioner, 58 F.2d 118 (6th Cir. 1932); Tye, Pointers in Bad Debts, Worthless Securities and Other Business Losses, N.Y.U. Sixth INST. on Fed. TAx. 681, 682 (1948). The debt must have had value when acquired; a "Ioan" cannot be deducted if when made there was no expectation of repayment either because it was a contribution to capital, American Cigar Co. v. Commissioner, 66 F.2d 425 (2d Cir. 1933) ; Houston Chronicle Publishing Co., 3 T.C. 1233 (1944), or because the creditor intended to make a gift, Young, Inc. v. Commissioner, 120 F.2d 159 (1st Cir. 1941) ; Estate of Carr V. Van Anda, 12 T.C. 1158 (1949), aff'd, 192 F.2d 391 (2d Cir. 1951).

Unless unpaid rent, wages, salary, etc. have been included as income by the creditor they cannot later be deducted as bad debts. See, e.g., John L. Seymour, 14 T.C. 1111 (1950) ; U.S. Treas. Reg. 118, \$ 39.23(k)-2 (1951).

Losses, deductible under INT. REv. CoDE of 1954, $\$ 165$, and bad debts are mutually exclusive. Spring City Foundry Co. v. Commissioner, 292 U.S. 182 (1934).

INT. REv. CODE of 1954, $\$ 166$ (a)-(c) substantially follows the bad debt provisions under the Int. Rev. Code of 1939, $\S 23(\mathrm{k})(1)-(6)$, as amended, 56 Stat. 820-22 (1942) and 58 STAт. 35 (1944). For the purpose of this discussion the same result would be reached under either statute.

2. INT. REv. Cope of 1954, § 166(a) (1). Unused deductions may be applied as net operating loss carrybacks and carryovers. Id. $\$ 172$.

3. "When satisfied that a debt is recoverable only in part, the Secretary or his delegate may allow such debt, in an amount not in excess of the part charged off within the taxable year, as a deduction." Id. $\$ 166(\mathrm{a})(2)$.

A taxpayer may, but need not, deduct for partial worthlessness in each year that some partial worthlessness develops. He may also wait until further worthlessness occurs, and deduct the total accumulated partial worthlessness at that date, or he may wait until the debt is completely worthless. E. Richard Meinig Co., 9 T.C. 976 (1947) ; Moock Elec. Supply Co., 41 B.T.A. 1209 (1940) ; G.C.M. 18525, 1937-1 CuMr. BuLL: S0.

A charge-off, which is a reduction in valuation of the asset on the taxpayer's books, must be established for a partial deduction. Trinco Industries, Inc., 22 T.C. 959 (1954).

4. INT. REv. CODE of 1954, § 166(d) (1) (B). Short term capital losses can be offset fully against capital gains, but against ordinary income only to the extent of $\$ 1,000$. Id . $\$ 1211$ (b). Capital losses may be carried forward for five years subject to the limitations in id. $\$ 1212$.

For a discussion of the distinction between business and nonbusiness debts see Guterman, Some Problems in the Deduction for Bad Debts, 63 HARv. L. REv. 832 (1950).

5. INT. REv. CODE of 1954, \$166(d) (1) (A). 
otherwise be uncollectible is not mentioned by the Code. ${ }^{\circ}$ Nor has recent case law answered the question whether such a debt becomes "worthless" within the meaning of the Code so long as the security remains unliquidated.7

In the case of Loewi v. Ryan ${ }^{8}$ the Court of Appeals for the Second Circuit permitted a taxpayer to deduct a nonbusiness bad debt in the year she liquidated her security, although apart from the collateral, the debt was uncollectible many years earlier, and liquidation was postponed solely for tax purposes. The taxpayer had made a $\$ 450,000$ loan to her brother in 1929 which was repayable on demand. ${ }^{9}$ The debt was eventually secured by shares of corporate stock and a one-half interest in a New York Stock Exchange seat. The debtor never repaid any of the loan, and the taxpayer admitted she knew as early as 1937 that, apart from the collateral, the debtor had no assets of any consequence. $^{10}$ In 1943 most of the stock was sold, the proceeds of approximately $\$ 20,000$ applied in reduction of the indebtedness, and in 1944 the remainder of the collateral, including the interest in the Stock Exchange seat, was sold for about $\$ 14,000.11$ The taxpayer claimed that in 1944 the debt became entirely worthless and entitled her to a deduction that year of $\$ 416,000$. The Commissioner disallowed the deduction because the taxpayer avoided liquidation of the collateral until 1944 solely for the reason that from 1938 to 1943 her capital gains were not sufficient to permit substantial utilization of the bad debt deduction. ${ }^{12} \mathrm{He}$ considered that the taxpayer had no privilege to post-

6. The purpose of security is to secure performance of an obligation. There are two classes, collateral or property security, and personal security. By collateral security is meant any property, negotiable stock or bonds, or documentary evidence of a claim against, or ownership in, property that is conveyed to the creditor as a pledge for the repayment of money lent, or as a guarantee for the performance of a contract. By personal security is meant a guaranty of the payment of money by one person for another. Personal security consists of a guarantor's promise alone; there is no pledge of his property. MuNN, ENCYClopedia of Banking and FinanCe 726 (1937).

7. Compare Industrial Trust Co. v. Commissioner, 206 F.2d 229 (1st Cir. 1953), and Marcus Boyd, 4 CCH Tax Ct. Mem. 293 (1945) (prevents total worthlessness), with Leopold Spingarn, 7 CCH Tax Ct. Mem. 498 (1948) (debt worthless).

8. 229 F.2d 627 (2d Cir. 1956), reversing 55-1 U.S.T.C. If 9445 (S.D.N.Y. 1955).

9. Actually Mrs. Loewi loaned her brother $\$ 350,000$, and her husband loaned him a one-quarter interest in a seat on the New York Stock Exchange which they valued at $\$ 100,000$. Loewi v. Ryan, 55-1 U.S.T.C. $\ 9445$ at 55,087 (S.D.N.Y. 1955). The bad debt deduction was claimed by both Mr. and Mrs. Loewi, who had filed a joint income return for 1944. The courts treated the two loans as one debt in deciding the legal questions. Ibid.; Loewi v. Ryan, 229 F.2d 627 (2d Cir. 1956).

10. Brief for Appellees, app. p. 3a, Loewi v. Ryan, 229 F.2d 627 (2d Cir. 1956).

11. Brief for Appellants, p. 5, Loewi v. Ryan, 229 F.2d 627 (2d Cir. 1956).

12. The Commissioner pointed out that in 1938, when the Loewis released the brother's obligation, they had net taxable capital gains of $\$ 8,115.87$, that in each of the years 1939 through $1943 \$ 13,000$ was the maximum of their net taxable capital gains, but that for 1944 the Loewis had net taxable capital gains of $\$ 84,128.26$. Brief for Appellees, p. 7 , Loewi $v$. Ryan, 229 F.2d 627 (2d Cir. 1956). However, for the years 1938-41 the Commissioner should have presented figures representing the net taxable income, rather than the net taxable gains, of the Loewis. While the distinction between business and nonbusiness debts 
pone liquidation for tax purposes alone. This position was upheld in a district court when the taxpayer sued for a refund. ${ }^{13}$ But the Second Circuit reversed the judgment, ruling that the taxpayer was permitted to liquidate or refrain from liquidating her security for whatever purposes she thought most profitable, including the reduction of her taxes. ${ }^{14}$

The Second Circuit's reasoning was based on the premise that the existence of security prevents a nonbusiness debt from being "entirely worthless" in a year when the unsecured portion is uncollectible. ${ }^{15}$ The court relied on several business debt cases, ${ }^{10}$ which indicate that if an otherwise worthless debt is covered by some security, the debt is not wholly worthless, but the taxpayer may claim the optional partial deduction. ${ }^{17}$ The Second Circuit also indicated a desire to correlate tax law with commercial law on the subject of security. ${ }^{18}$ Commercial law permits a creditor whose debtor has defaulted to refrain from selling his security as he sees fit as long as the value of the security is less than the amount of the debt. ${ }^{19}$ The court disapproved a Tax Court decision which

introduced in the Revenue Act of 1942 was made retroactive to December 31, 1938, 56 Stat. 822 (1942), the Loewis must have believed until 1942 that their bad debt deduction would be offset against ordinary income. Barton, Federal Incone, Estate and GifT Tax Laws Correlated 74-76 (9th ed. 1944). The Commissioner's error was of no signifcance in this case because the net income of the Loewis from 1938-41 never exceeded $\$ 10,154.24$ annually. Brief for Appellees, app. pp. 30a-41a, Loewi v. Ryan, 229 F.2d 627 (2d Cir. 1956).

13. Loewi v. Ryan, 55-1 U.S.T.C. I 9445 (S.D.N.Y. 1955). The government defended the action on three grounds. First, it contended that no bona fide debt ever existed. Second, it urged that assuming a valid debt, the collateral securing the obligation was taken in satisfaction of the debt prior to 1944. Finally, the jury was asked to find that the debt, if it ever existed, became worthless prior to 1944 . The jury brought in a general verdict in favor of the government.

The appellants based their appeal solely on claimed errors in the trial court's charge as it related to the third ground. The charge complained of was as follows:

"However, if you find that the debts were secured, as I have instructed you, consider the security with all the other factors I have mentioned in determining whether the debts became worthless in 1944.

"And in connection, as I say, with whether the debt became worthless in 1944 I charge you that the postponement of a bad debt deduction until the collateral is applied to the debt cannot be permitted solely because of the existence of this collateral. Such postponement must be shown to have been in good faith and bona fide for a taxpayer."

Id. at 55,093 .

14. 229 F.2d at 629 n.1. This ruling was based on Supreme Court decisions holding the taxpayer's motive to be irrelevant in determining his tax liability. But see San Joaquin Brick Co. v. Commissioner, 130 F.2d 220, 227 (9th Cir. 1942).

15. 229 F.2d at 629 .

16. Ibid. These and similar decisions are cited note 32 infra.

17. For discussion of the deduction for partial worthlessness, see note 3 supra.

18. 229 F.2d at 629 .

19. Restatement, Security $\$ \S 48,52$ (1941) ; Osborne, Mortgages 921-38, 991-95 (1951).

However, to follow that law in this context would open a very substantial loophole in 
would prevent deferring a bad debt deduction indefinitely by requiring the taxpayer to take the deduction at the time the unsecured amount became hopelessly worthless. ${ }^{20}$ "If that [result] is desired," reasoned the Second Circuit, "there must be some change in the Act . . . or Regulations." who accepted the court's premise, dissented on the ground that a taxpayer may refrain from foreclosing on security for any valid business reason, but not tax reduction. Moreover, he would make the taxpayer's judgment in that respect controlling, as long as the taxpayer acted in good faith. ${ }^{22}$

Permitting a taxpayer to postpone the deduction because of the existence of security is to allow him to withhold it in a low-income year and take the claim when it inures to his greatest advantage. ${ }^{23}$ Moreover, the reasoning of the decision extends to business as well as to nonbusiness bad debts, and thus would also permit shifting deductions from ordinary income. ${ }^{24}$ This privilege

the Code. When such loopholes have arisen, Congress has not hesitated to deviate from commercial law in amending the Code. See Reiling, Developing a Law of Income Tanation, 32 TAxes 546, 566-68 (1954); INT. REv. CODE of 1954, $\$ \$ 671-78$ (grantors and others treated as substantial owners); id. $\$ 704$ (e) (family partnerships); id. $\$ 1239$ (gains from sales between related parties). Nor have courts been bound by non-tax law. See text at notes 47,48 infra (constructive receipt).

20. Leopold Spingarn, 7 CCH Tax Ct. Mem. 498 (1948). In that case, the unsecured portion of a $\$ 400,000$ debt was uncollectible at the time of the debtor's death in 1937 although the creditor held $\$ 80,000$ worth of collateral which had been pledged as security for the debt. The creditor did not liquidate the collateral until 1943, at which time he claimed a bad debt deduction for the unsecured portion. He argued that the debt was not and could not have been determined to be worthless until the sale of all the collateral. But the tax court replied that a taxpayer "cannot be permitted to hold collateral indefinitely and take a deduction as it suits his fancy when the debt in excess of the collateral was hopelessly bad in prior years." Id. at 501.

21. 229 F.2d at 629 .

22. Id. at 630. Judge Frank reasoned that it was not Congress' intent that a taxpayer have the choice of the taxable year in which to deduct a loss since the statute provides it definite period in which bad debts must be deducted, i.e., "the taxable year" within which they become worthless.

23. Under Loewi, it would be possible to plan manipulation at the time a nonbusiness debt was made. Nonbusiness debts are always suspect; frequently they are merely a guise for gifts to relatives and friends made with no intention of repayment. See Note, 65 YaLE L.J. 247 n.4 (1955). Thus, the "loan" can be secured by some collateral of little more than nominal value. This allows the creditor to choose any year in which to liquidate the security. In addition, the fact that some security was given also serves to give a gift the semblance of a valid loan. See note 1 supra. Although the majority makes clear that the security must be of "substantial value," 229 F.2d at 629 , this test introduces difficult questions of proof in individual cases. Furthermore, the security need not be given when the loan is made. Thus in Loezwi, the last pledge of stock was made in 1935, two years before the taxpayer admitted she knew the debt was probably uncollectible. See note 10 supra and accompanying text.

24. The statutory language in regard to worthlessness is identical for both types of debts, INT. REv. CODE of 1954, \& 166(a) (1), (d) (1) (B), and the court recognized the similarity of treatment by referring to business debt cases for support. 229 F.2d at 629 
of manipulating deductions is out of step with frequent holdings that, in the absence of statutory authority, events of tax significance may not be shuffled to and fro between taxable periods. ${ }^{25}$ Federal income tax statutes have been consistently drawn with the purpose of fixing, so far as is practicable, the precise year in which a deduction must be claimed. ${ }^{26}$ That year is the one which causes taxable income to coincide most closely with preferred accounting principles. ${ }^{27}$ In particular, the decision is inconsistent with the tenor of the bad

Judge Frank also understood the majority to agree that their ruling applied to business bad debts secured by collateral. Id. at 631 .

Some language in the opinion indicates that the decision would not apply to business debts. Id. at 629-30. Presumably, because a "business" taxpayer may deduct any worthless portion of a debt, INT. REv. CoDE of 1954, § 166(a) (2), he would not be allowed to postpone a deduction solely for tax advantage. However, the deduction for partial worthlessness is optional and once a taxpayer has chosen not to exercise the option, the Loever conclusion that collateral prevents complete worthlessness seems as compelling in the "business" as in the "nonbusiness" cases. This has been the conclusion reached by the business debt cases prior to Loewi. See note 32 infra.

25. In Avery v. Commissioner, 22 F.2d 6 (5th Cir. 1927), the court held that to permit manipulation of the time for a bad debt deduction would defeat the intent and purpose of the law. Stephenson v. Commissioner, 43 F.2d 348, 351 (8th Cir. 1930) ; Hiram R. Lloyd, 34 B.T.A. 301 (1936) ; Katharine H. Putnam, 31. B.T.A. 241, $244-45$ (1934). U.S. Treas. Reg. 118, §39.23(k)-1 (d) (1951).

In non-bad debt cases the Supreme Court has recognized the principle. Burnet v. Sanford \& Brooks Co., 282 U.S. 359, 363 (1931) (reporting income and losses) ; Virginian Hotel Corp. v. Helvering, 319 U.S. 523, 525 (1943) (depreciation).

"[N]either income nor deduction may be accelerated or postponed from one taxable year to another in order to reflect the ultimate result of a business transaction." Harrold v. Commissioner, 192 F.2d 1002, 1003 (4th Cir. 1951).

See Magill, Taxable Income 245-54 (rev. ed. 1945).

26. Belser v. Commissioner, 174 F.2d 386, 389 (4th Cir. 1949). See Int. Rev. Cone of $1954, \S 461$ (a).

For discussion of statutory attempts to block postponing the receipt of income see Anthony P. Miller, Inc. v. Commissioner, 164 F.2d 268 (3d Cir. 1947). For discussion of congressional reaction to shifting of losses suffered on performing a contract see Burnet v. Sanford \& Brooks Co., supra note 25. The Supreme Court has held that the purpose of Int. Rev. Code of 1939, \& 24(b), (c), as amended, 67 Stat. 617 (1953) (now INr. Rev. CODE of 1954, $\$ 267$ ) ". . . was to put an end to the right of taxpayers to choose . . their own time for realizing taxlosses. ..." McWilliams v. Commissioner, 331 U.S. 694, 700 (1947).

When Congress has wanted to permit special treatment for problems of fluctuating income it has done so specifically. See INT. Rev. CoDE of 1954, $\$ \$ 453$ (installment sales), 1301-0. (lump sum compensation).

27. Congress has indicated that ".. . it is essential that the income tax laws be brought into harmony with generally accepted accounting principles. ..." S. REP. No. 372, 84th Cong., 1st Sess. 6 (1955) ; see also S. Rep. No. 1622, 83d Cong., 2d Sess. 62 (1954) ; H.R. ReP. No. 1337, 83d Cong., 2d Sess. 48 (1954).

INT. REv. CODE OF 1954, § 446 directs that computation of taxable income be based on the taxpayer's accounting methods except where departure is necessary to reflect income clearly.

For examples of successful efforts to eliminate divergences between tax and business accounting, and suggestions as to future improvements, see Mills, Tax Acconnting and 
debt section which would deny taxpayers the opportunity to choose the year in which to take the deduction. The Code was amended in 1942 to make the test of bad debt worthlessness an objective one of worthlessness in fact. ${ }^{28}$ Prior to that time a taxpayer could properly claim a deduction in the year in which he ascertained an indebtedness to have become worthless, regardless of the year in which it actually became uncollectible. ${ }^{29}$ The "good faith" requirement of Judge Frank ${ }^{30}$ is also unsuitable. It employs a subjective test similar to the one Congress rejected. Moreover, it would not be an effective barrier against tax avoidance because of the wide area of discretion it would leave to the taxpayer. ${ }^{31}$

Business Accounting. Present Status and Remaining Differences, \& NAT'L TAx J. 69 (1955) ; Lasser and Peloubet, Tax Accounting v. Connercial Accounting, S7 J. AccounTANCY 279 (1949) ; Edelman, Is Income Tax Accounting "Good" Accounting Practice?, 24 TAXES 112 (1946). Accounting principles would require a debt to be written off at the time the debt becomes uncollectible. Similarly, if a debt becomes partially worthless, the loss should be recognized pro tanto at that time. See Paton, Essentials of Accounting 415 (1938).

28. Redman v. Commissioner, 155 F.2d 319 (1st Cir. 1946) ; Cittadini v. Commissioner, 139 F.2d 29 (4th Cir. 1943) ; Watson v. Fahs, 120 F. Supp. 424 (S.D. Fla. 1954). "Debts which become worthless within the taxable year" was substituted for "debts ascertained to be worthless and charged off within the taxable year." BARToN, op. cit. supra note 12, at 74-75; H.R. REP. No. 2333, 77th Cong., 2d Sess. 44, 76 (1942) ; S. REP. No. 1631, 77th Cong., 2d Sess. 89-90 (1942); 88 Cong. Rec. 6377 (1942); Hearings Before the Senate Finance Committee, 77th Cong., 2d Sess., at 51, 692, 1612 (1942).

The Revenue Act of 1942 also extended the period for claims for refund or credit from three to seven years. The three year period was objectionable because in many instances where there was a disallowance of a deduction taken in the wrong year the statute of limitations barred amendment of the return for the allegedly proper year. The seven year statute of limitations does not apply to partially worthless debts. INT. REv. CoDE of 1954, $\$ 6511$ (d).

29. BARTON, op. cit. supra note 12, at 74-75.

In addition, the debt had to be charged within that period. Ibid. Many courts held that even if a reasonably prudent person would have believed a debt actually became worthless in a given year, the taxpayer might deduct the debt in a later year, provided that in good faith it was then that he first ascertained the fact of worthlessness. Harris v. Commissioner, 140 F.2d 809 (2d Cir. 1944); Jones v. Commissioner, 38 F.2d 550 (7th Cir. 1930). Other courts, to avoid the frequent coincidence of a taxpayer's judgment of worthlessness and a year of high income, disregarded the element of good faith and insisted that the taxpayer ascertain worthlessness in the year that a reasonable man would have done so. Reading Co. v. Commissioner, 132 F.2d 306 (3d Cir. 1942) ; Curtis v. Helvering, 110 F.2d 1014 (2d Cir. 1940) ; Sabath v. Commissioner, 100 F.2d 569 (7th Cir. 1938) ; Avery v. Commissioner, 22 F.2d 6 (5th Cir. 1927).

30. Loewi v. Ryan, 229 F.2d 627, 630 (2d Cir. 1956) (dissenting opinion); see Leopold Spingarn, 7 CCH Tax Ct. Mem. 498 (1948).

31. It would not be difficult for the taxpayer to allege non-tax motives for postponing liquidation, such as an anticipated rise in the value of security. Whether or not this "business reason" actually motivated the postponement would require inquiry into the state of the creditor's mind. But even though the postponement is for bona fide reasons, it would seem preferable to require the deduction when an ascertainable loss has occurred: i.c., 
The authorities relied on by Loewi are not compelling. The secured business debt cases, all decided by lower and intermediate courts, consider that the existence of security causes an otherwise wholly bad debt to be only partially worthless. ${ }^{32}$ Although this is a possible interpretation of what Congress envisaged as a partial loss, it is by no means a necessary one. The partial deduction was introduced to enable taxpayers to reflect accurately their net income for the taxable year. ${ }^{33}$ This was to be achieved by permitting a creditor to deduct the uncollectible portion of a debt at the time it became worthless even though his debtor had some assets which might later be available to satisfy the rest of the debt. $^{34}$ A situation clearly within the scope of the partial loss enactment occurs when the debtor becomes bankrupt and the creditor must wait until a later tax year for the trustee's distribution. ${ }^{35}$ In this type of situation, the Code recognizes that the creditor cannot control the time for fixing the loss completely; to require him to postpone the deduction until the debt became wholly worthless would not reflect economic reality. However, at the time Congress

when the worthlessness of the unsecured portion of the debt is established. See note 27 supra. At this point it should be noted, however, that if the debt were evidenced by a corporate security, which was secured by collateral, the bad debt section would be inapplicable, see INT. REv. CoDE of 1954, \$ 166 (e), although the same reasoning might conceivably apply.

32. Industrial Trust Co. v. Commissioner, 206 F.2d 229 (1st Cir. 1953) ; Old Colony Trust Associates v. Hasset, 150 F.2d 179 (1st Cir. 1945) ; Marcus Boyd, 4 CCH Tax Ct. Mem. 293 (1945) ; Cyrus S. Eaton, P-H 1942 T.C. Mem. Dec. ff 42,282; John H. Wood Co., 46 B.T.A. S95 (1942) ; Howard W. Georger, P-H 1941 B.T.A. Mem. Dec. \ 41,376; Kessler Oil \& Gas Co., 41 B.T.A. 31 (1940). A taxpayer is not compelled to take a deduction for a debt which is only partially bad. See note 3 supra.

Several of these cases also reasoned that until collateral was sold the uncollectible balance of a debt could not in any way be ascertained. But it has been held not necessary that collateral actually be sold or disposed of as a prerequisite to a partial bad debt deduction. Ross v. Commissioner, 72 F.2d 122 (7th Cir. 1934); Dominion Nat'1 Bank, 26 B.T.A. 421 (1932). Furthermore, when property is accepted in payment of a debt, deduction of the excess of the debt over the value of the property is allowable only in the year that the property is received, and not in a subsequent year when it is sold. Fairmount Foundry, Inc., 42 B.T.A. 1087 (1940) ; Rev. Rul. 30, 2 Cuss. Burl. 138 (1920). It is frequently necessary to determine the fair market value of property. See, e.g., INr. REV. CoDE of 1954, $\$ \$ 1014,1015$ (property acquired from decedent or by gift) ; PEARCE, InCONIE TAX FundAMentrals 33-34 (1937); Commissioner v. Stone's Estate, 210 F.2d 33 (3d Cir. 1954); McNamara v. Commissioner, 210 F.2d 505 (7th Cir. 1954) ; Note, 64 YALE L.J. 269 (1954) (valuation of employee stock options). It would not therefore appear difficult to subtract the value of the collateral from the amount of the debt. See note 50 infra and accompanying text.

33. John E. Saddler, 2 B.T.A. 1305, 1306 (1925) ; H.R. ReP. No. 350, 67th Cong., 1st Sess. 11 (1921) ; 61 Cong. Rec. 5201, 5289, $5939-41$ (1921); Paul, Studies in Federal TAXATION 247 (1937).

34. INr. Rev. CoDE of 1954, § 166(a) (2) ; U.S. Treas. Reg. 118, § 39.23(k)-1(c) (1951).

35. Grant G. Simmons, 4 T.C. 478 (1944) ; H.R. REP. No. 350, 67th Cong., 1st Sess. 11 (1921) ; 61 Cong. Rec. 5201, 5289, 5939-41 (1921) ; PAvi, op. cit. supra note 33, at 247. 
enacted this relief provision there was no indication that when the unsecured portion of a secured debt became bad a deduction would be denied under the wholly worthless provision. Indeed, as the Loewi case illustrates, when the taxpayer does have control over the time when the loss may be fixed, ${ }^{30}$ to permit him to postpone the deduction serves only a tax avoidance purpose. The secured business debt cases are unsound as precedent on yet another ground. All but two of them were decided under the Code as it existed before the 1942 amendments when taxpayers were allowed considerable latitude in determining the year in which a debt became worthless. ${ }^{37}$ Under that tax policy it was not unreasonable to permit secured creditors to postpone their deductions because the security had not been liquidated. The remaining two cases relied solely on the earlier decisions without mention of the statutory change. ${ }^{38}$ The substantial changes in the bad debt section in 1942, introducing an objective standard of worthlessness, would justify the Loewi court in disregarding these cases. ${ }^{39}$

It might also be suggested that section $39.23(\mathrm{k})-1(\mathrm{c})$ of the Treasury Regulations, discussing the effect of collateral, is opposed to treating a secured debt as wholly worthless until the security is liquidated. ${ }^{40}$ But the pertinent

36. The secured creditor already has dominion over the security since he has possession if the property is pledged, Restatement, Securrty $\$ \$ 4-8$ (1941); Isaacs, Pledge, 12 ENcyc. Soc. Scr. 166 (1934), title if the security is a mortgage, or equitable ownership in any other method of transfer to secure a debt, OsBonne, Mortgages 32-34, 54-59, 306-15, $406-10$ (1951) ; Sanborn, Lien, 9 Encxc. Soc. Scr. 456 (1933); Sturges, Mortgage, 11 ENcyc. Soc. Scr. 32 (1933). In some cases the secured creditor will not have an opportunity to sell the security at a reasonable price because of economic conditions. However, it is difficult to recognize this factor without also introducing the creditor's subjective determinations of what constitute business reasons. See note 31 supra and accompanying text.

37. See note 29 supra.

38. Industrial Trust Co. v. Commissioner, 206 F.2d 229 (1st Cir. 1953) and Marcus Boyd, 4 CCH Tax Ct. Mem. 293 (1945).

39. See note 28 supra and accompanying text.

40. U.S. Treas. Reg. 118, § 39.23 (k) -1 (c) (1951).

Section $39.23(\mathrm{k})-3(\mathrm{a})$ of the Regulations might also be considered to imply that the deduction need not be taken until the time of the sale of mortgaged or pledged property.

"If mortgaged or pledged property is lawfully sold ... for less than the amount of the debt, and the portion of the indebtedness remaining unsatisfied after such sale is wholly or partially uncollectible, the mortgagee or pledgee may deduct such amount ... a as a bad debt for the taxable year in which it has become wholly worthless or is charged off as partially worthless."

However, the regulation might well be interpreted to apply only if the sale is conducted in the year in which the unsecured portion becomes wholly worthless. The tense of the phrase "has become" would be incorrect if the draftsman were referring only to past worthlessness (should have used "became") or if he were referring to the future (should have used "become's") but is appropriate if the year of sale is the same as the year in which the uncollectible deficiency has become worthless. "Has become" was introduced into the Regulations in 1942 at the same time that the 1942 amendments to the Code were adopted to make the text of bad debt worthlessness objective. T.D. 5234, 1943 Cun. Bull. 119, 125. 
portion of the section is ambiguous." It concludes "In determining whether a debt is worthless in whole or in part the Commissioner will consider ... the value of the collateral, if any, securing the debt and the financial condition of the debtor. . . ." 42 While it might be argued that this sentence supports the theory that the existence of collateral prevents an otherwise worthless debt from being wholly worthless, it is equally capable of referring only to the determination of the amount of a deduction. The regulation does not appear to have been cited for either interpretation. ${ }^{43}$

To hold that a debt becomes wholly worthless in the year the unsecured portion becomes uncollectible would be consistent with the language of the Code. The "debt which becomes worthless" 44 could be interpreted to refer to the unsecured portion of a secured debt since it is the only amount that can ever be deducted. ${ }^{45}$ At the time this is uncollectible the debt is worthless for tax purposes, and the deduction should be required. Only then would the amount of the deduction be considered. For this purpose the value of the security is taken into account.

Another approach which the Loewi court could have taken would have been to find a constructive purchase of the security by the taxpayer at the time the unsecured portion of the debt became uncollectible. ${ }^{46}$ The value of the security would be applied to reduce the indebtedness leaving the remainder of the debt unsecured, uncollectible and deductible only in that taxable year. While there is no support for a constructive purchase theory in the Code, the inauguration of such a doctrine by the courts to close a loophole in tax law is not without precedent. Thus, in deciding when a cash basis taxpayer is to report income, judges refuse to be bound by a strict reading of the Code's provision

This ambiguity cannot be solved by reference to the judicial decisions since no court appears to have construed the phrase.

41. Courts have disregarded Treasury Regulations which were ambiguous or in conflict with judicial statutory interpretation. Estate of Sanford v. Commissioner, 308 U.S. 39, $48-49$ (1939) ; Burnet v. Chicago Portrait Co., 285 U.S. 1, 16, 20 (1932).

42. U.S. Treas. Reg. 118, $\S 39.23(\mathrm{k})-1$ (c) (1951). The wording of this sentence has not been altered since its insertion into the Regulations in 1921.

43. Of the cases cited in note 32 supra, and other relevant cases, only Industrial Trust Co. v. Commissioner, 206 F.2d 229 (1st Cir. 1953) mentions $\S 39.23(\mathrm{k})-1(\mathrm{c})$, and that opinion makes no particular reference to the sentence in question.

44. INT. REv. CODE OF 1954, \& 166(a) (1).

45. There is no loss for the portion of the debt which is secured and by definition, if the value of the security diminishes, the unsecured portion of the debt increases.

"Consequences cannot alter statutes, but may help to fix their meaning." Cardozo, J., in In the Matter of Rouss, 221 N.Y. 81, 91, 116 N.E. 782, 785, rearg. denied, 221 N.Y. 667, 117 N.E. 1083 (1917), cert. denied, 246 U.S. 661 (1918).

46. It is possible that the taxpayer could not foreclose on the security even though the debt were actually worthless. For example, the principal indebtedness may not yet be in default and without an acceleration clause, the creditor would be unable to liquidate the collateral. Since, in this case, the creditor would have no control over the time for fixing the loss, the constructive purchase theory would be inapplicable. See text at notes 33-36 supra. 
that income items be included in the year in which they are "received by the taxpayer."47 Rather, to prevent taxpayers from selecting the year in which they will report income already earned, courts apply the judicially created doctrine of constructive receipt. ${ }^{48}$

Under either of the proposed alternatives to the Second Circuit's decision in Loezor, security held by a nonbusiness debt taxpayer should generally be subject to the capital gains and losses subchapter of the Code. ${ }^{40}$ The basis of the security would be its value at the time the unsecured portion of the debt became uncollectible. When the nonbusiness debt taxpayer sells the security any increase in value realized by him over its basis will result in a capital gain, and any decrease in value, in a capital loss. ${ }^{50}$ Hence, the taxpayer would eventually be entitled to the identical capital loss deduction he received under the Loewi decision, but he would not be able to select the most advantageous year in which to take the deduction.

However, in the hands of a business debt taxpayer security should not generally be considered a capital asset for purposes of capital gains and losses treatment. The Code definition of a capital asset, ${ }^{51}$ as interpreted by the

47. INr. REv. CoDE of $1954, \S 451$ (a).

48. "Not recognizing constructive receipt of income as income realized would open the door to fraud by leaving it within the power of the taxpayer to reduce income to possession at such time as would best suit his taxation purposes. Such right of selection does not rest with the taxpayer, nor does it find approval in the cases." Loase v. United States, 74 F.2d 147, 150 (8th Cir. 1934); Hedrick v. Commissioner, 154 F.2d 90 (2d Cir. 1946). See, generally, Comment, Constructive Receipt: When Must the Taxpayer Pay?, 45 InI. L. REv. 77 (1950).

49. INT. REv. CoDE of 1954, §§ 1201-41. Section 1221 defines a capital asset as any "property held by the taxpayer (whether or not connected with his trade or business). .." except property listed in a series of exclusionary clauses. These clauses now cover almost every type of property held by a taxpayer in connection with his trade or business. Since a "'non-business' debt means a debt other than-

(A) a debt created or acquired (as the case may be) in connection with a taxpayer's trade or business; or

(B) a debt the loss from the worthlessness of which is incurred in the taxpayer's trade or business,"

id. $\S 166$ (d) (2), security for a nonbusiness debt would ordinarily be a capital asset. In the rare case where the security is used in the creditor's trade or business, its disposition will lead to ordinary gain or loss treatment.

50. Id. $\S 1222$.

If, at the time of sale, the value of the security exceeds the uncollected portion of the debt plus interest and selling expenses, the excess must be turned over to the debtor, REstatement, Security $\$ 49$ (1941); Osborne, Mortgages 1005 (1951), and does not constitute gain to the creditor.

INT. REv. CoDE of 1954, \$ 111, treating recovery of bad debts, should not be applicable to any gain to the creditor since for tax purposes the creditor would be treated as owner of the collateral; in that view the gain would not represent a recovery. If the gain were treated as a recovery of the bad debt and $\$ 111$ held applicable, it would reduce the amount of the gain to the extent that the bad debt deduction taken in a prior year did not result in tax benefit. See Merchants Nat'l Bank v. Commissioner, 199 F.2d 657 (5th Cir. 1952).

51. See note 49 supra. 
Supreme Court in Corn Products Refining Co. $v$. Commissioner, ${ }^{52}$ excludes property held incident to a taxpayer's regular business, rather than as an investment. ${ }^{53}$ Prior to default, a business debt taxpayer holds security as an integral part of his business operation; he retains it after the unsecured portion of the debt becomes worthless only if there is hope of thereby reducing the amount of his loss on the business debt. ${ }^{54}$ If the security is not treated as a capital asset, a subsequent sale by the taxpayer will result in ordinary gain or loss to offset or increase the ordinary loss deduction taken at the time the unsecured portion of the debt became uncollectible. The business debt taxpayer will ultimately receive the identical total deduction he receives under the Loewi interpretation of the Code, with the opportunity to manipulate the time of the deduction eliminated. If the security is held to represent an investment by the taxpayer, and thus to be a capital asset, its sale following a rise in value will offset capital gain against the ordinary loss of the bad debt deduction; if the value falls, part of the taxpayer's loss will be capital instead of ordinary. Assuming the correctness of a court's classification of security as an investment asset, ${ }^{b 5}$ these results will accurately reflect the business transactions that will have occurred: bad debt deduction from ordinary income when the unsecured portion of the debt became worthless, investment in the security by the creditor in lieu of liquidation, and subsequent capital gain or loss.

The possibility which Loewi creates for secured creditors to manipulate the time for bad debt deductions could be readily eliminated if the Commissioner would promulgate a new regulation covering secured bad debts. This regulation should provide that: in the case of secured business or nonbusiness debts, when the creditor is able to liquidate the security, the debt shall be treated as having become worthless within the taxable year in which the surrounding circumstances indicate that the unsecured portion of the debt is wholly worthless and uncollectible. ${ }^{56}$ The amount of the deduction shall be the difference

52. 350 U.S. 46 (1955) ; Note, 65 YALE L.J. 401 (1956).

53. "Congress intended that profits and losses arising from the everyday operation of a business be considered as ordinary income or loss rather than capital gain or loss. The preferential treatment provided by [the capital assets provisions] ... applies to transactions in property which are not the normal source of business income. It was intended 'to relieve the taxpayer from ... excessive tax burdens on gains resulting from a conversion of capital investments, and to remove the deterrent effect of those burdens on such conversions.' Burnet v. Harmel, 287 U.S., at 106 [1932]." Corn Products Refining Co. v. Commissioner, stipra note 52 , at 52 .

54. Several cases which seem to have anticipated Corn Products Refining Co. v. Commissioner, 350 U.S. 46 (1955), held that the cost of maintaining collateral following insolvency of the debtor may be deducted as ordinary and necessary business expenses. First Nat'1 Bank \& Trust Co. v. Jones, 143 F.2d 652 (10th Cir. 1944); Dominion Nat'l Bank, 26 B.T.A. 421 (1932). However, if the collateral secures a non-business debt, the cost of maintenance cannot be deducted as an expense. United States v. Mellinger, 228 F.2d 688 (5th Cir. 1956).

55. See Note, 65 Yale L.J. 401 (1956) for treatment of the classification question.

56. See U.S. Treas. Reg. 118, § 39.23(k)-1(d) (1951). 
between the amount of the debt and the fair market value of the security at the time the unsecured portion of the debt became wholly worthless. Thereafter this fair market value will be considered the basis for the security, which will be treated as property in the hands of the creditor. The proposed regulation would not prevent partial deduction for a business debt whenever the unsecured portion of the debt became partially worthless. Until a clarifying regulation is adopted courts should read the existing Code and Regulations in the light of the Supreme Court's statement that taxation "is an intensely practical matter"'s7 and should render a solution that will preclude manipulation of deductions by secured creditors.

57. Farmers Loan \& Trust Co. v. Minnesota, 280 U.S. 204, 212 (1930). 